\title{
Enabling advanced cell therapies (EnACT): invitation to an online forum on resolving barriers
} to clinical translation

\author{
"EnACT welcomes participation from both the stem cell and cell therapy \\ communities, recognizing that there is significant overlap in these fields, that the \\ challenges are similar and that many translational researchers and companies \\ work with multiple cell types."
}

KEYWORDS: business models " commercialization " ethics " incentives " intellectual property rights $\approx$ public policy $\approx$ regulation $\approx$ stem cell therapy

Stem cell (SC) therapies hold the promise of improved outcome for diseases and conditions for which there are currently limited or no treatment options [1]. As research advances towards the clinic, it becomes increasingly important to reduce significant organizational and institutional barriers to progress. Barriers include: ensuring that essential knowledge flows to those who need it; developing precompetitive tools to assist in therapeutic development; facilitating regulatory assessment; and effectively managing intellectual assets in a highly collaborative and networked field. These barriers may be overcome by pre-emptive and effective public policy guided by a realistic assessment of these barriers to translational research [2-4].

In this editorial, we introduce EnACT an online forum to be opened on 15 October 2012 for international translational cell therapy research communities to address solutions to key nonscience barriers (Figure 1). EnACT welcomes participation from both the SC and cell therapy communities, recognizing that there is significant overlap in these fields, that the challenges are similar and that many translational researchers and companies work with multiple cell types. However, the focus is on translational $\mathrm{SC}$ research. We will seed EnACT with issues identified in 22 key informant interviews conducted in Canada and the USA in 2011-2012, as well as from policy reports and other publications. If additional barriers are identified, they will be added to EnACT, allowing participants to comment and propose solutions.

EnACT will be structured to recognize the complexity and diversity of products and procedures that may be characterized as SC-based therapies $[5,6]$. Some therapies comprise the direct administration of SCs and some involve transplantation of differentiated SC progeny after culture in vitro, while others depend on secondary products, such as matrices and scaffolds, whether these are seeded prior to transplant or used to recruit SCs in vivo, to provide the structure for cell growth. Cell-based products may be autologous or allogeneic. In addition, there is a variety of SC types that may be used directly after harvest or following laboratory manipulation. While some SC therapies might be mass produced as pharmaceuticals, others may be based on single-unit production, similar to current SC products, using hospital-based or point-of-care harvesting, manipulation and administration [7-9]. Since solutions will largely depend on the specific context of SC use, participants will first be asked to identify their field of translational expertise, and will then be directed to the area in the forum discussing relevant issues, where they can share their specific interests or experiences.

\section{"...we introduce EnACT - an online forum to be opened on 15 October 2012 for}

international translational cell therapy research communities to address solutions to key nonscience barriers."

Not surprisingly, our initial key informants identified funding and related incentives as the major barrier to translational SC research. There was, however, little agreement on where incremental funding should be directed. Opinions included increased funding for basic biology research, funding of clinical trials, as well as commercialization activities, technology development, training of the next generation of researchers and skilled technicians, large

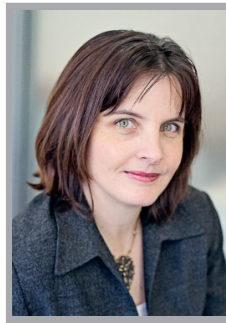

Tania Bubela

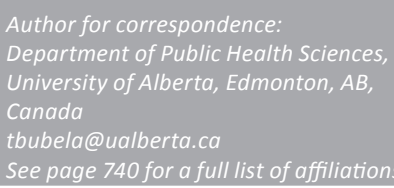

See page 740 for a full list of affiliation.

Amir Reshef

Matthew D Li

Harold Atkins

Timothy Caulfield

Emily Culme-Seymour

E Richard Gold

Judy Illes

Rosario Isasi

Christopher McCabe

Ubaka Ogbogu

James Piret

Chris Mason 


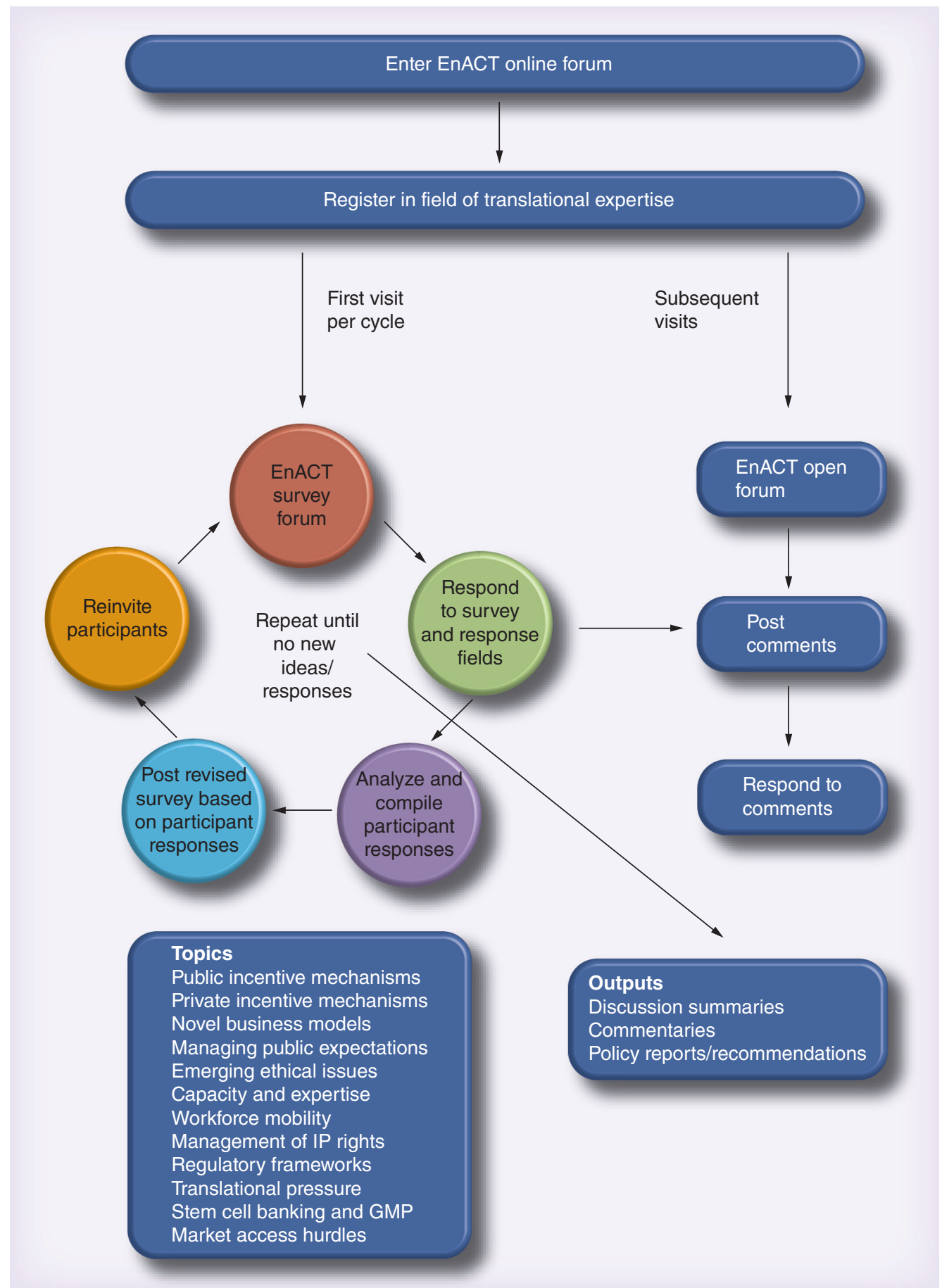

\section{Figure 1. Structure of the EnACT online forum.} IP: Intellectual property.

animal model research and the establishment of clinical research infrastructures to support both the supply of clinical-grade materials and clinical trials. While governments may directly fund some of these activities through a variety of granting programs, additional investment will be required from the private sector, including venture capital firms, angel investors and the pharmaceutical sector. Interviewees also recognized the increasing importance and profile of philanthropic and charitable funding sources, including patient advocacy communities. Additional novel funding mechanisms include tapping interested members of the public through mechanisms such as crowd-sourcing.

The goal of the forum is not to pit communities of researchers against each other by establishing a hierarchy of funding or other 
priorities. Instead, it is to discuss mechanisms to address identified barriers or gaps, recognizing that what works well in one jurisdiction may not translate to another. For example, strategies used in the USA, which dominates biotechnology in support and research output, may not be applicable to mid-sized economies that lack a strong pharmaceutical sector and have a more conservative, risk-averse business community. Neither may such strategies be appropriate for emerging economies in the process of developing a skill-base and responsive regulatory environment. Nevertheless, lessons may be learned, even in the USA, especially following the current global economic slowdown and its negative impact on biotechnology research and development (R\&D). Of course, lessons should also be learned from incentive structures that have been successful in other, more established high-technology fields.

One unifying theme, however, is the highly collaborative nature of translational SC research. Similar to many complex areas of translational science, bringing SC research to the clinic will require significant investment in multidisciplinary, multistakeholder, multinational and highly collaborative R\&D. Discussion of funding mechanisms, therefore, has moved beyond standard investigator-initiated awards and awards targeted to support exceptional researchers. Instead, many public funders of research have established programs that promote research networks and require partnerships between academic researchers and the biotechnology or pharmaceutical sectors, often across borders. For example, the California Institute for Regenerative Medicine supports multidisciplinary teams that collaborate to move a research project to the clinic within a 4-year period [101]. The Canadian Stem Cell Network partners with universities, industry, government departments and agencies, health charities and not-for-profit organizations, as well as international SC organizations, to support translational SC research [102]. Some such programs are international in scope, such as the Cancer Stem Cell Consortium (CSCC), which brings together funding agencies in Canada and California interested in furthering SC research [103]. The goal of the Consortium is to assemble a large-scale repository of tumor samples for research, including biomarker identification.

Beyond direct public funding for collaborative multisectoral translational SC research, other incentive mechanisms may be brought to bear. These are required to bridge the ever-widening valley of death - the gap between public research support and private financing [10]. The perception among interviewees, supported by the trend of declining venture capital support for biotechnology [11], is that private capital is difficult to raise unless based on positive Phase II clinical trial results. In the heyday of the biotechnology boom, private financial investment could be gained based on strong preclinical data. Venture capital is especially difficult to raise in smaller markets, outside of the USA. The issue is exacerbated for cell therapies, with commentators noting the difficulty of turning SC therapies into profitable business ventures $[9,12]$, deterring private sector investment in the field. EnACT will therefore address the critical need to develop creative and novel business models reflective of the diversity of products, processes and services involved in the clinical application of SC therapies.

\section{"EnACT will be a venue for the stem cell community to provide their anonymous views on potential solutions to the key barriers facing their respective subfields."}

EnACT will explore the utility of incentive mechanisms for private funding and investment beyond partnering with government-funded researchers through cash or in-kind industry contributions. Such incentives, many of which being suggested by the interviewees, include government-backed investment management corporations or loan guarantees and tax incentives such as tax holidays, R\&D tax credits or depreciation tax shield incentives [13]. The latter occurs when a government allows businesses to depreciate a percentage of their capital expenditures up to a set limit [13], as the USA did in response to the recent recession [104]. An interesting incentive used in India, Taiwan and China to support the development of the semiconductor industry is capital expenditure (Capex) incentives, whereby governments reimburse a percentage of capital expenditures (25\% in India and up to $50 \%$ in China and Taiwan) [105]. Such a model could be useful to support the growth of GMP facilities for cell processing. Other potential incentives include flow-through shares that encourage investment in high-risk endeavors such as oil and mineral exploration programs [106], as well as moving rapidly to an Initial Public Offering (IPO). IPOs, however, have not been frequent events in the biotechnology and cell therapy sectors for several years [14]. 
Other incentives targeted at industry include systems for accelerated regulatory approvals, such as the Priority Review, Accelerated Approval and Fast Track mechanisms in the USA [107]. Such mechanisms may be targeted specifically at orphan diseases [15]. In addition, a variety of prizes may be awarded for innovations that meet certain criteria of safety, efficacy and fulfilling of unmet needs [16]. Such prizes may address perceived market failures and have been proposed to incentivize the development of medicines and vaccines for neglected diseases in developing countries [16]. Prizes have been used to incentivize specific technological developments such as the Archon Genomics X Prize of US $\$ 10$ million to greatly improve the speed and accuracy as well as reduce the cost of human genome sequencing [108]. In other words, no potential incentives will be off the table. EnACT will provide brief descriptions of each, the situations in which incentives have been used and any evidence of success or failure. Participants will be asked to assess the applicability of the mechanisms to their field or activities, to propose other established potential mechanisms or to propose blue-sky novel mechanisms. The result will be a collective report on potential policy options for the multiple stakeholders engaged in translational SC research.

\section{"We look forward to a rigorous and lively debate on the key nonscience challenges facing the translational stem cell research community."}

While funding and incentives are significant issues of concern to the community, other issues will also be addressed in the forum. These were identified through our interviews and through the interests of the partners hosting the forum. Issues additional to public and private incentive mechanisms and novel business models will be:

- The management of public expectations with respect to $\mathrm{SC}$ research that have given rise to the phenomenon of SC tourism [17];

- Emerging areas of ethical concern such as the off-shoring of clinical trials to jurisdictions with lower standards of ethical and regulatory oversight [18];

- The lack of capacity and expertise at all levels including the training of clinician researchers, running of clinical trials, regulatory capacity, commercialization and business acumen, risk assessment for investment and health technology assessment;

- Retention of highly qualified personnel in a global marketplace, sometimes referred to as the 'brain-drain problem' [19];

- Creative management of intellectual property rights in a highly collaborative environment [20,21];

- Emerging issues for regulators, especially the rise of potential applications of induced pluripotent SCs [22];

- Responding to increasing institutional pressures to move research to the clinic [23];

- The establishment of and support for biorepositories [24];

- Clear assessment of market access hurdles [25].

Consideration of this last issue is imperative since public and private health systems are the key market for SC therapies. Market access is dependent on demonstrated value in addition to safety and efficacy. Value is a function of cost to the healthcare system and impact on the health status of patients. There is therefore a critical need to examine the challenges for SC therapies in clearing market access value hurdles and a need to develop mechanisms so that realistic market access considerations can feed back to commercial SC development strategies.

In conclusion, EnACT will be a venue for the SC community to provide their anonymous views on potential solutions to the key barriers facing their respective subfields. EnACT will be divided into two areas. The first area - EnACT Open Forum - will be an interactive, moderated discussion forum among participants on issues of interest. The second key area - EnACT Survey Forum - will be a more structured survey combined with free-text response fields to expand on specific issues. In this area, EnACT will provide participants with prepared descriptions of issues and potential solutions, ask participants to determine their importance or applicability and enable participants to provide feedback on provided material and to justify their assessments. Every 3 months, the responses from EnACT Survey Forum will be compiled and integrated into a modified or new set of issues and solutions, and again opened for comment. This iterative process will be repeated until no new ideas emerge. In this context, the goal is not consensus, but a 
canvassing of opinion. Participants may respond to all or a subset of key issues.

The forum will open at www.ualberta. $\mathrm{ca} /$ enact on 15 October 2012 and EnACT Survey Forum will close for the first iteration on 31 January 2012. EnACT Open Forum will remain accessible. We look forward to a rigorous and lively debate on the key nonscience challenges facing the translational SC research community.

Financial \& competing interests disclosure

T Bubela, H Atkins, T Caulfield, J Illes, ER Gold, $C M c C a b e$ and J Piret are principal investigators with the Canadian Stem Cell Network. EnACT is supported by three
Strategic Core Grants: Public Policy and ELSI Research in the Stem Cell Field from the Canadian Stem Cell Network (principal investigators: $T$ Bubela, $T$ Caulfield and $B M$ Knoppers). C Mason is the principal investigator and E Culme-Seymour is an investigator on the British Regen Industry Tool Set (BRITS) project funded by the Technology Strategy Board under their Regenerative Medicine Program: Value Systems and Business Modelling. The authors have no other relevant affiliations or financial involvement with any organization or entity with a financial interest in or financial conflict with the subject matter or materials discussed in the manuscript apart from those disclosed.

No writing assistance was utilized in the production of this manuscript.

\section{References}

1 Weissman IL. Translating stem and progenitor cell biology to the clinic: barriers and opportunities. Science 287, 1442-1446 (2000).

2 Plagnol AC, Rowley E, Martin P, Livesey F. Industry perceptions of barriers to commercialization of regenerative medicine products in the UK. Regen. Med. 4(4), 549-559 (2009).

3 Martin PA, Coveny C, Kraft A, Brown N, Bath P. The commercial development of stem cell technology: lessons from the past, strategies for the future. Regen. Med. 1(6), 801-807 (2006).

4 Winickoff DE, Saha K, Graff GD. Opening stem cell research and development: a policy proposal for the management of data, intellectual property, and ethics. Yale J. Health Policy Law Ethics IX, 52-127 (2009).

5 von Tigerstrom B, Schroh E. Regulation of stem cell-based products. Health Law J. 15, 175-226 (2007).

6 von Tigerstrom B. The challenges of regulating stem cell-based products. Trends Biotechnol. 26, 653-658 (2008).

7 von Tigerstrom B. The Food and Drug Administration, regenerative sciences, and the regulation of autologous stem cell therapies. Food Drug Law J. 66, 479-506 (2012).

8 Martin PA, Coveney C, Kraft A, Brown N, Bath P. Commercial development of stem cell technology: lessons from the past, strategies for the future. Regen. Med. 1(6), 801-807 (2006).

9 Rao MS. Funding translational work in cell-based therapy. Cell Stem Cell 9(1), 7-10 (2011).

10 Mason C, Brindley DA, Culme-Seymour EJ, Davie NL. Cell therapy industry: billion dollar global business with unlimited potential. Regen. Med. 6(3), 265-272 (2011).

11 Brindley DA, Reeve BC, Sahlman WA et al. The impact of market volatility on the cell therapy industry. Cell Stem Cell 9(5), 397-401 (2011)

12 Little M, Hall W, Orlandi A. Delivering on the promise of human stem-cell research. EMBO Rep. 7, 1188-1192 (2006).

13 Stockfisch JA. Investment incentive, taxation, and accelerated depreciation. Southern Economic J. 24(1), 28-40 (1957).

14 Brau JC, Francis B, Kohers N. The choice of IPO versus takeover: empirical evidence. J. Business 76(4), 583-612 (2003).

15 Ridley DB, Grabowski HG, Moe JL. Developing drugs for developing countries. Health Affairs 25(2), 313-324 (2006).

16 Adler JH. Eyes on a climate prize: rewarding energy innovation to achieve climate stabilization. Harvard Env. Law Rev. 35(1), 1-45 (2011).

17 Lau D, Ogbogu U, Taylor B, Stafinski T, Menon D, Caulfield T. Stem cell clinics online: the direct-to-consumer portrayal of stem cell medicine. Cell Stem Cell 3, 591-594 (2008).

18 Sipp D. Stem cell research in Asia: a critical view. J. Cell. Biochem. 107, 853-856 (2009).

19 Levine AD. Research policy and the mobility of US stem cell scientists. Nat. Biotechnol. 24, 865-866 (2004).

20 Bubela T, Strotmann A, Noble R, Morrison S. Commercialization and collaboration: competing policies in publicly-funded stem cell research? Cell Stem Cell 7, 21-30 (2010).

21 Bubela T, FitzGerald GA, Gold ER. Recalibrating intellectual property rights to enhance translational research collaborations. Sci. Transl. Med. 4, $122 \mathrm{~cm} 3$ (2012).

22 Zarzcecny A, Scott C, Hyun I et al. iPS cells: mapping the policy issues. Cell 139, 1032-1037 (2009).

23 Bubela T, Caulfield T. Role and reality: technology transfer at Canadian universities. Trends Biotechnol. 28, 447-451 (2010).

24 Isasi R, Knoppers BM. From banking to international governance: fostering innovation in stem cell research. Stem Cells Intl 2011, 498132 (2011).

25 McCabe C, Claxton K, O’Hagan A. Why licensing authorities need to consider the net value of new drugs - addressing the tension between licensing and reimbursement. Int. J. Technol. Assess. Health Care 24, 140-145 (2008).

\section{Websites}

101 California Institute for Regenerative Medicine (CIRM).

www.cirm.ca.gov/content/developmenttherapeutic-antibodies-targeting-humanacute-myeloid-leukemia-stem-cells

102 Stem Cell Network - Partners. www.stemcellnetwork.ca/index. php? page $=$ partners $\&$ hl $=$ eng

103 Cancer Cell Consortium. www.cancerstemcellconsortium.ca

104 Federal Tax Watch (2011). Maxwell, Locke and Ritter LLP. www.mlrpc.com/docs/2011_sept_ftw.pdf

105 Singh S. 25\% concession on capex for the semiconductor biz on the cards. http://businesstoday.intoday.in/story/ new-semiconductor-policy-25percentconcession-on-capital-expenditure-for-thesemiconductor-industry/1/14494.html

106 Canada Revenue Agency. www.cra-arc.gc.ca/tx/bsnss/tpcs/fts-paa/ menu-eng.html 
107 US FDA. Speeding access to important new therapies. Fast Track, Accelerated Approval and Priority Review.

www.fda.gov/forconsumers/byaudience/ forpatientadvocates/

speedingaccesstoimportantnewtherapies/ ucm128291.htm

108 Archon Genomics X Prize. http://genomics.xprize.org

\section{Affiliations}

- Tania Bubela, Amir Reshef \& Matthew D Li Department of Public Health Sciences, University of Alberta, Edmonton, AB, Canada

\section{- Harold Atkins}

The Ottawa Hospital Research Institute, The Ottawa Hospital General Campus, Ottawa, ON, Canada

- Timothy Caulfield \& Ubaka Ogbogu Faculty of Law, University of Alberta, Edmonton, AB, Canada

- Emily Culme-Seymour London Regenerative Medicine Network, London, UK

- E Richard Gold Faculty of Law, McGill University, Montreal, QC, Canada

- Judy Illes

Faculty of Medicine \& National Core for Neuroethics, University of British Columbia, Vancouver, BC, Canada
- Rosario Isasi

Centre of Genomics \& Policy, Department of Human Genetics, Faculty of Medicine, McGill University, Montreal, QC, Canada

- Christopher McCabe

Faculty of Medicine, University of Alberta, Edmonton, AB, Canada

- James Piret

Michael Smith Laboratories \& Department of Chemical \& Biological Engineering,

University of British Columbia, Vancouver, BC, Canada

\section{- Chris Mason}

Advanced Centre for Biochemical Engineering, UCL, London, UK 